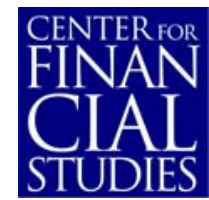

No. $2007 / 15$

Financial Literacy and Retirement Preparedness:

Evidence and Implications for Financial Education Programs

Annamaria Lusardi and Olivia S. Mitchell 


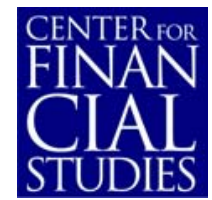

\section{Center for Financial Studies}

The Center for Financial Studies is a nonprofit research organization, supported by an association of more than 120 banks, insurance companies, industrial corporations and public institutions. Established in 1968 and closely affiliated with the University of Frankfurt, it provides a strong link between the financial community and academia.

The CFS Working Paper Series presents the result of scientific research on selected topics in the field of money, banking and finance. The authors were either participants in the Center's Research Fellow Program or members of one of the Center's Research Projects.

If you would like to know more about the Center for Financial Studies, please let us know of your interest.

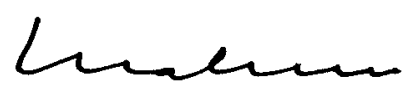

Prof. Dr. Jan Pieter Krahnen

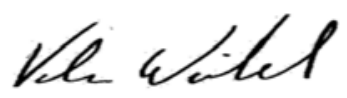

Prof. Volker Wieland, Ph.D. 


\title{
Financial Literacy and Retirement Preparedness: Evidence and Implications for Financial Education Programs*
}

\author{
Annamaria Lusardi ${ }^{1}$ and Olivia S. Mitchell ${ }^{2}$
}

January 2007

\begin{abstract}
:
Economists are beginning to investigate the causes and consequences of financial illiteracy to better understand why retirement planning is lacking and why so many households arrive close to retirement with little or no wealth. Our review reveals that many households are unfamiliar with even the most basic economic concepts needed to make saving and investment decisions. Such financial illiteracy is widespread: the young and older people in the United States and other countries appear woefully under-informed about basic financial concepts, with serious implications for saving, retirement planning, mortgages, and other decisions. In response, governments and several nonprofit organizations have undertaken initiatives to enhance financial literacy. The experience of other countries, including a saving campaign in Japan as well as the Swedish pension privatization program, offers insights into possible roles for financial literacy and saving programs.
\end{abstract}

JEL Classification: D80, D91, G11

Keywords: Financial and Economics Knowledge, Retirement Seminars, Financial Decisionmaking.

\footnotetext{
* The research reported herein was pursuant to a grant from the US Social Security Administration (SSA) funded by the Michigan Retirement Research Center (MRRC) and the Pension Research Council at The Wharton School. We thank Chetan Mehta and Kate Flaim for outstanding research assistance. Opinions and errors are solely those of the authors and not of the institutions with whom the authors are affiliated. The findings and conclusions of this paper do not represent the views of the SSA, any agency of the Federal Government, or the MRRC. (C) 2006 Lusardi and Mitchell. All Rights Reserved

1 Dartmouth College and NBER

2 The Wharton School and NBER
} 


\section{Financial Literacy and Retirement Preparedness: Evidence and Implications for Financial Education Programs}

Workers and retirees have increasingly been asked to take on an unprecedented degree of responsibility for their retirement and other saving, as defined benefit pensions decline and government programs face insolvency in one country after another. As a result, consumers now confront a bewildering array of financial decisions and a wide range of financial products ranging from 401(k) plans and Roth and regular Individual Retirement Accounts, phased withdrawal plans to annuities, and many more. This process implies that it is becoming ever more important for households to acquire and manage economic know-how. But in practice, there is widespread financial illiteracy: Many households are unfamiliar with even the most basic economic concepts needed to make sensible saving and investment decisions. This has serious implications for saving, retirement planning, retirement, mortgage, and other decisions, and it highlights a role for policymakers working to boost financial literacy and education in the population. The Organization for Economic Cooperation and Development (OECD, 2005) defines "financial education" as:

"The process by which financial consumers/investors improve their understanding of financial products and concepts and, through information, instruction, and/or objective advice, develop the skills and confidence to become more aware of financial risks and opportunities to make informed choices, to know where to go for help, and to take other effective actions to improve their financial well-being."

Building upon this definition, we provide a review of the current state of financial literacy and financial education programs, and we discuss whether consumers/investors appear to possess the financial literacy necessary to process financial information and formulate adequate saving plans.

We also offer some examples of efforts to enhance financial literacy. 


\section{U.S. Evidence on Financial Literacy}

Researchers have undertaken several recent studies of financial literacy in the United States. For instance, a survey conducted for the National Council on Economic Education (NCEE) by Harris Interactive in 2005 indicated that nearly all U.S. adults believe that it is "important to have a good understanding of economics." But despite this lofty goal, the evidence shows that actual financial knowledge is sorely deficient for both high school students and working-age adults. The survey consisted of a 24 -item questionnaire on topics grouped into categories including "Economics and the Consumer;" "Money, Interest Rates and Inflation;" and "Personal Finance." When results were tallied using standard grading criterion, adults had an average score of $\mathrm{C}$ while the high school population fared even worse, with most earning an $\mathrm{F}$ (average score of 53\%). Particularly troublesome were the sections dealing with money, interest rates, inflation, government and trade, and personal finance. The report also indicated gender and minority gaps: White students and adults tended to score higher than their Black and Hispanic peers, and women scored lower than men.

Low levels of financial literacy are confirmed by related research by the Jump\$tart Coalition for Personal Financial Literacy focusing on U.S. high school students (Mandell, 2004). That group's biannual survey on basic personal financial management skills and how to improve them showed in both 2004 and 2006 that students fared poorly on credit management and personal finance questions, and knew little about stocks, bonds, and other investments.

Americans' lack of financial knowledge has been confirmed in the larger population by Hilgert and Hogarth (2002) who used data from the University of Michigan's 2001 Survey of Consumers focusing on respondents ages 18-97. Some 1000 respondents were given a 28 -

\footnotetext{
${ }^{1}$ Some of the questions include the following: "Where do most people derive the largest portion of their personal income?"; "What are business most likely to do when banks reduce their interest rates?"; and "Why do people prefer to buy mutual funds rather than stocks in individual companies?"
} 
question True/False Financial Literacy quiz, with questions examining knowledge about credit (e.g. credit card statements, APR, debt payments); saving patterns (e.g. interest rates, mutual funds, insurance); mortgages (e.g. interest rate fluctuations, refinancing, use of one's home as collateral); and general financial management (e.g. emergency funds, employer responsibilities in retirement, bank obligations). Overall, that study found that Americans could correctly answer only two-thirds of the questions. They were best informed regarding mortgages $(81 \%$ correct responses), followed by saving patterns (67\% correct), credit cards (65\% correct), and general financial management (60\% correct). Respondents were less knowledgeable about mutual funds and the stock market: only half knew that mutual funds do not pay a guaranteed rate of return, and $56 \%$ knew that "over the long-term, stocks have the highest rate of return on money invested." On dividing respondents into two groups - those more and those less financially knowledgeable - the study confirmed that less financially knowledgeable respondents were more likely to be single, relatively uneducated, relatively low income, minority, and either young or old (not middle-aged).

To explore financial literacy in more depth, we have devised and fielded a purpose-built module on planning and financial literacy for the 2004 Health and Retirement Study (HRS), a survey that covers respondents over the age of 50 (Lusardi and Mitchell, 2006a). This module includes questions measuring how workers made saving decisions, how they collected the information for making these decisions, and, most importantly, whether they possessed the financial literacy needed to make informed decisions. Our research shows that only half of the HRS respondents surveyed could answer two simple questions regarding interest compounding and inflation correctly. Furthermore only one-third could correctly answer those two questions as 
well as an additional one on risk diversification. We also found that financial illiteracy was particularly acute for Blacks and Hispanics, women, and those with low educational attainment. In related work, we employed data from the 2004 HRS to evaluate whether Baby Boomers are relatively well informed about financial matters (Lusardi and Mitchell 2006b). Specifically we focused on some 1,700 Early Boomers age 51-56 in 2004. The following financial literacy questions were posed to these respondents:

1) "If the chance of getting a disease is 10 percent, how many people out of 1,000 would be expected to get the disease?"

2) "If 5 people all have the winning number in the lottery and the prize is 2 million dollars, how much will each of them get?"

For respondents who answered either the first or the second question correctly, the following question was asked:

3) "Let's say you have 200 dollars in a savings account. The account earns 10 percent interest per year. How much would you have in the account at the end of two years?"

We called these variables, respectively, the "Percentage Calculation," the "Lottery Division," and the "Compound Interest" questions. We also determined whether the respondent could be deemed "Politically Literate," by considering a question on whether he knew the names of the U.S. President and Vice President.

Table 1 summarizes how this group of Boomers answered the economic and political literacy questions. The good news is that over $80 \%$ got the Percentage Calculation question correct. But only about half could divide $\$ 2$ million by 5 to get the Lottery Division right. And more distressingly, only $18 \%$ correctly computed the compound interest question; of those who got that interest question wrong, $43 \%$ undertook a simple interest calculation, thereby ignoring the interest accruing on both principal and interest. These are uncomforting findings, especially 
considering that these respondents are only a dozen years from retirement and, one surmises, have handled numerous financial decisions during their lives. It is also worth noting that fully one-fifth of the sample could not name either the U.S. President or Vice President.

Further details on financial literacy appear in Figure 1, which reports the distribution of correct responses for respondents in different educational and racial/ethnic groups. For all four measures, financial literacy rises steeply with education: the more educated are much more likely to answer the economic and political literacy queries correctly. Moreover, Blacks and Hispanics are less likely to answer correctly than Whites. There are also similarities across answers. For instance, all three racial/ethnic groups score over $50 \%$ on the percentage calculation, but all three score low on the compound interest question.

Our findings confirm those provided by Bernheim $(1995,1998)$, who was among the first to warn of the lack of financial literacy among savers and investors. It also confirms studies of smaller and more limited samples. For example, the State of Washington sponsored a survey to assess financial literacy among its residents (Moore, 2003) and concluded that people are particularly uninformed about financial instruments. Specifically, most respondents did not know the inverse relationship between bonds prices and interest rates. They were also uninformed about mutual funds: Many did not know what a no-load mutual fund was, or that mutual funds do not pay a guaranteed rate of return. More than one-third did not know that stocks had higher returns than bonds over the last forty years, and many did not know about risk diversification. Finally, a large fraction of these respondents did not understand interest rates, which was especially troublesome since a subset of the respondents had applied for loans.

Similar findings are reported by Agnew and Szykman (2005), who devised a financial literacy survey as part of an experiment held at a mid-size public university in the Southeast 
designed in the spirit of a John Hancock Financial Services Defined Contribution Plan Survey (2002). Their respondents — college employees, tourists, parents of students, and local construction workers - produced similar patterns. All knew little about mutual funds and they could not explain even simple differences between stocks, bonds, and money market mutual funds. This research also confirmed conclusions from surveys conducted by the Employee Benefit Research Institute. For example, their survey in 1996 showed that only 55 percent of workers knew that U.S. government bonds provided lower returns than the U.S. stock market over the past 20 years.

\section{International Evidence on Financial Literacy}

Evidence from outside the United States on financial literacy is no more comforting. In 2005, the ANZ Banking Group conducted an extensive survey on the financial practices of consumers in Australia and New Zealand. The Australian survey of some 3,500 randomly chosen respondents age $18+$ evaluated understanding of topics ranging from investment fundamentals, retirement planning and financial records, to basic arithmetic. In the Financial Terms section of the survey, $67 \%$ of respondents said they understood compound interest, but a mere $28 \%$ were rated as having a "good level" of comprehension when faced with an actual problem to solve. As in the United States case, those with low levels of financial literacy also had low education and income. This survey also confirmed the gender gap, with women concentrated in the lowest $20 \%$ of the literacy distribution. In the New Zealand survey of respondents age $18+$, similar results obtained. Some $54 \%$ of respondents believed that fixed income investments would provide higher returns than stocks over an 18-year period, and again financial literacy was strongly positively correlated with socio-economic status. 
The results extend to Europe, where Miles (2004) showed that UK borrowers display a weak understanding of mortgages and interest rates. The UK Financial Services Authority also concluded that younger people, those in low social classes, and those with low incomes were the least sophisticated financial consumers. Christelis, Jappelli, and Padula (2005) documented that respondents in several European nations scored low on financial numeracy and literacy scales.

Meanwhile, on the other side of the Pacific, a Japanese consumer finance survey showed that $71 \%$ of adult respondents knew little about equity and bond investments, and more than $50 \%$ lacked any knowledge of financial products (OECD 2005). A Korean youth survey conducted by the Jump\$tart coalition in 2000 showed that young Koreans fared no better than their American counterparts when tested on economics and finance knowledge, with most receiving a failing grade. Again, a positive correlation was detected between family income and education, and the students' performance on the financial literacy test (OECD, 2005).

While financial knowledge is weak, it is also the case that people tend to be more confident in their abilities than should be warranted. For instance, a German survey conducted by Commerzbank AG in 2003 found that $80 \%$ of respondents were confident about their understanding of financial issues, but only $42 \%$ could answer half of the survey questions correctly (OECD, 2005). Similar patterns are consistent in the United States, the United Kingdom, and Australia. Indeed, consumers' overconfidence regarding their financial knowledge may be a deterrent to seeking out professional advice, thus widening the 'knowledge gap'.

\section{Linking Financial Literacy and Economic Behavior}

While the low levels of financial literacy are troubling in and of themselves, policymakers are most concerned by the potential implications of financial illiteracy for 
economic behavior. One example is offered by Hogarth, Anguelov, and Lee (2005), who demonstrate that consumers with low levels of education are disproportionately represented amongst the "unbanked," those lacking any kind of transaction account.

To further examine how financial illiteracy is tied to economic behavior, we used the 2004 HRS to connect financial knowledge to retirement planning abilities (Lusardi and Mitchell 2006b). Table 2 reveals that, for this population over the age of 50, those who are more financially knowledgeable are also much more likely to have thought about retirement. Further, planners are most likely to know about of interest compounding, which makes sense inasmuch as it is critical for effective saving plans. Even after accounting for factors such as education, marital status, number of children, retirement status, race, and sex, we still found that financial literacy plays an independent role: those who understand compound interest and can do a simple lottery division are much more likely to have planned for retirement. This is important, since in related work, we have shown that lack of planning is tantamount to lack of saving (Lusardi and Mitchell, 2006a; Lusardi, 1999).

Other authors have also confirmed the positive association between knowledge and financial behavior. For example, Calvet, Campbell, and Sodini (2005) find that more financially sophisticated households are more likely to buy risky assets and invest more efficiently. Kimball and Shumway (2006) report a large positive correlation between financial sophistication and portfolio choice. Hilgerth, Hogarth, and Beverly (2003) also document a positive link between financial knowledge and financial behavior.

Campbell (2006) has highlighted how household mortgage decisions, particularly the refinancing of fixed-rate mortgages, should be understood in the larger context of 'investment mistakes' and their relation to consumers' financial knowledge. This is a particularly important 
topic, given that most US families are homeowners and many have mortgages. The sad reality is that many households are confused about the terms of their mortgages. Campbell (2006) also finds that younger, better-educated, better-off White consumers with more expensive houses were more likely to refinance their mortgages over the 2001-2003 period when interest rates were falling. His findings are confirmed by Bucks and Pence (2006), who examine whether homeowners know the value of their home equity and the terms of their home mortgages. They show that many borrowers underestimate the amount by which their interest rates can change and that low-income, low-educated households are least knowledgeable about the details of their mortgages (especially those with adjustable rate mortgages). Further evidence of biases is provided by Stango and Zinman (2006) who well document the systematic tendency of people to underestimate the interest rate associated with a stream of loan payments. The consequences of this bias are important: those who underestimate the annual percentage rate (APR) on a loan are more likely to borrow and less likely to save.

Consumers are not only poorly informed about mortgages or incorrect about interest rates, they also know little about Social Security and pensions, two of the most important components of retirement wealth. Close to half of workers in the HRS sample analyzed by Gustman and Steinmeier (2004) could not report their type of pension plan, and an even larger portion was ignorant of future Social Security benefits, confirming earlier findings from Mitchell (1988). There is mounting evidence that knowledge about pensions and Social Security affects retirement decisions (Chan and Huff Stevens (2003) and Mastrobuoni (2005)).

\section{Programs Aimed at Fostering Retirement Saving}


Responding to reports of widespread financial illiteracy and workers' under-saving, some employers have begun to offer employees financial education in the workplace. For instance, retirement seminars are often provided by firms that offer defined contribution pensions (DC), in order to enhance employee interest in and willingness to participate in these voluntary saving programs. Whether such programs have an impact is, of course, a key question.

The idea is that if seminars provide financial information and improve financial literacy, they should reduce workers' planning costs and thus enhance retirement saving. Yet it is difficult to evaluate the impact of such retirement seminars for several reasons. One is that participation in these seminars is typically voluntary, so workers who attend them probably differ from those who do not (for instance, they may have more retirement wealth and thus, stand to benefit differently from seminars than low wealth workers). Another is that workers who participate in a retirement seminar may also be more patient or diligent, personal characteristics associated with higher wealth accumulation. Third, as noted by Bernheim and Garrett (2003), employers may offer retirement education as a remedial device, when they perceive workers to be under-saving. This leads to a negative rather than positive correlation between seminars and saving. These complexities have meant that few researchers have been able to sort out the effects of seminars cleanly, and empirical findings are mixed. ${ }^{2}$

Fortunately, the HRS can overcome some of these data challenges. For instance, Lusardi $(2002,2004)$ posits that if financial education is offered to those who need it most, the saving impacts would be strongest among the least educated and least wealthy. As shown in Table 3, the HRS data bear this out: retirement seminars are found to have a positive wealth effect mainly in the lower half of the wealth distribution and particularly for the least educated. Estimated effects

\footnotetext{
${ }^{2}$ See, among others, McCarthy and Turner (2000), Bernheim (1995, 1998), Bayer, Bernheim and Scholz (1996), Clark and Schieber (1998), Muller (2003), Clark and D'Ambrosio (2002 2003), Clark, D'Ambrosio, McDermed and Sawant (2003) and Bernheim and Garrett (2003).
} 
are sizable, particularly for the least wealthy, for whom attending seminars appears to increase financial wealth (a measure of retirement savings that excludes housing equity) by approximately $18 \%$. This effect derives mainly from the very poorest, where wealth increased by more than $70 \%$. The effect of financial education is also large for those with low education, where financial wealth rose almost $100 \%$. Of course these large percentage changes are measured off a low base, of only about $\$ 2000$ (Lusardi, 2004). Other authors have also suggested that financial education can be effective when targeted at the least well-off. For instance, Caskey (2006) finds that personal financial management education has positive impacts on the wealth and credit patterns of low- and moderate-income households.

Yet even when the impacts work in the predicted direction, they can be rather small in dollar terms. Thus Duflo and Saez $(2003 ; 2004)$ focus on non-faculty employees at a large university who where given financial incentives to participate in an employee benefits fair. The authors compared pension participation and contributions in that group with that of employees not induced to participate. Overall, they found that the program had fairly small effects: attending the fair did induce more employees to participate in the pension, but the increase in contributions was negligible. And good intentions do not always translate into desired behavior. For instance, Clark and D'Ambrosio (2003) and Clark, D'Ambosio, McDermed and Sawant (2003) report that exposing workers to retirement seminars does influence workers' stated desire to save more. Yet several authors, including Choi, Laibson, Madrian and Metrick (2004) and Madrian and Shea (2001), show that seminar participants who say they will start contributing to pensions or boost their contributions often fail to actually do so.

Further findings on the impact of financial education programs are available from Schreiner, Clancy, and Sherraden (2002). That project studied the effectiveness of Individual 
Development Accounts (IDAs), which are subsidized savings accounts targeted at the poor that provide matching contributions if the balance is used for a specific purpose (e.g. home purchase, starting a business, etc.). As part of the American Dream Demonstration, that study included 2,364 participants (in 2001) age 13-72, of whom $80 \%$ were female. The project had a financial education component, and the authors found that those with no financial education saved less than those exposed to the educational program. But the effect was nonlinear: after 8-10 hours of financial education, the result tapered off with no appreciable additional increases in saving after that.

\section{Historical Evidence and Privatization Episodes}

There are historical precedents for a governmental role in the design and implementation of programs aimed at increasing saving. For example, after WWII the Japanese government sought to build a saving culture among its citizens. Accordingly it launched a national campaign to promote saving (Bernheim, 1991), with public interest agencies including the Central Council of Savings Promotion and media dissemination techniques (leaflets and booklets, posters, advertisements, films, magazines, etc.) to instill "values of conservatism and frugality" in the Japanese population. This campaign built on the Japanese bonus or lump sum system (almost $16 \%$ of employee compensation during the 1950 s came from these annual bonuses), and it led financial institutions to court savers aggressively at bonus time with advertising campaigns and new financial instruments. Most households made it a rule to save half of their annual bonus, and Bernheim (1991) argues that this initiative may have played a role in Japan's high saving rate over the last several decades. 
Government involvement in financial education programs has also become important in light of many state pension reforms. For example, Sweden recently implemented an individual defined contribution account scheme as part of its social security system, giving workers responsible for investing part of their retirement money in capital markets. Contributors had to select from approximately 460 fund companies; the number of funds then burgeoned to more than 650 by 2004 (Sunden, 2004). The government also established a 'default' plan for participants who did not wish to make an active investment choice. Initially, to inform and educate the population about the new pension system, the National Social Insurance Board launched a major information campaign, and over two-thirds of participants made an active investment choice. But subsequently the educational effort declined and the fraction making an active investment election fell to about $10 \%$ of participants.

Another state pension reform that has required workers to make financial decisions is the much-vaunted individual account system in Chile, where a national mandatory defined contribution system was implemented in 1981. Workers must select a single pension administrator to manage their money, and within that structure, they can also choose in which of five accounts they will hold their money. Despite the fact that the system has been in place for 25 years, recent research using the Encuesta de Previsión Social (EPS) shows that participants are woefully under-informed about the pension system (Arenas et al., 2006). For instance, most Chilean workers do not know what they are required to contribute under the system, how much they pay in commissions, what the eligibility rules are for minimum guaranteed pensions, or how their funds are invested. Two-thirds of the system affiliates said they received reports on contributions and projected future benefits, but very few could give critical details such as the tax rates and fees they pay on the investments. Most participants also did not know their fund 
balances or details of how their money was invested. As in other cases, lack of knowledge is concentrated among those with poorer backgrounds, less education, and women. The analysts also compared workers' self-reports with administrative data on actual balances and contributions, and they found that levels of pension system knowledge are lowest among workers but highest among retirees; two-thirds of beneficiaries knew what kind of pension they were receiving, and about the same fraction knew their benefit amount. In general, those who knew their pension amounts were those receiving higher benefits. It is interesting that the more knowledgeable participants are also more likely to save additional amounts via a voluntary savings vehicle, underscoring the link between financial literacy and retirement saving behavior. One explanation for the low levels of financial literacy in the Chilean case is that the nation's pension reform was initially adopted during a dictatorship and little effort was devoted to raising awareness about the system. Recently, the new President's reform commission has proposed that the government create a pension education program to promote, spread, and teach workers about the need to save and invest for retirement (Consejo, 2006).

\section{Concluding Remarks}

Financial literacy surveys in many developed nations show that consumers are poorly informed about financial products and practices. This is troubling, in that financial illiteracy may stunt peoples' ability to save and invest for retirement, undermining their well-being in old age. It is also a matter of significant concern that these deficiencies are concentrated among particular population subgroups - those with low income and low education, minorities, and womenwhere being financially illiterate may render them most vulnerable to economic hardship in retirement. 
While more is being learned about the causes and consequences of financial illiteracy, it is still the case that one must be cautious when concluding that financial education has a potent effect on retirement saving. First, a small fraction of workers ever attend retirement seminars, so many are left untouched by this initiative. ${ }^{3}$ Second, widespread financial illiteracy will not be "cured" by a one-time benefit fair or a single seminar on financial economics. This is not because financial education is ineffective, but rather that the cure is inadequate for the disease. Third, the finding that people have difficulty following through on planned actions suggests that education alone many not be sufficient. Rather, it is important to give consumers the tools to change their behaviors, rather than simply delivering financial education. Fourth, people differ widely in their degree of financial literacy and saving patterns are very diverse (Browning and Lusardi, 1996). Accordingly, a "one-size-fits-all” education program will do little to stimulate saving and could even be a disincentive to participate in a financial literacy effort. For instance, in the Washington Financial Literacy survey, most respondents stated that they would prefer personalized ways to learn how to manage money, rather than attending information sessions (Moore, 2003).

Evidently, consumers require additional support for old-age retirement planning and saving. Also, education programs will be most effective if they are targeted to particular population subgroups, in order to address differences in saving needs and in preferences. As oldage dependency ratios rise across the developed world, and as government-managed pay-as-yougo social security programs increasingly confront insolvency, these issues will become increasingly important. So the crucial challenge is to better equip a wide range of households

\footnotetext{
${ }^{3}$ For example, in the sample used by Lusardi (2004) only $13 \%$ of older workers have ever attended a seminar offered by their employer.
} 
with the financial literacy toolbox they require, so they can better build retirement plans and execute them. 


\section{References}

Agnew, Julie and Lisa Szykman (2005), "Asset Allocation and Information Overload: The Influence of Information Display, Asset Choice and Investor Experience," Journal of Behavioral Finance, 6, pp. 57-70.

Australia and New Zealand Banking Group (2005), "ANZ Survey of Adult Financial Literacy in Australia," November.

Arenas de Mesa, Alberto, David Bravo, Jere R. Behrman, Olivia S. Mitchell, and Petra E. Todd. With assistance from Andres Otero, Jeremy Skog, Javiera Vasquez, and Viviana Velez-Grajales. (2006) "The Chilean Pension Reform Turns 25: Lessons from the Social Protection Survey," NBER Working Paper 12401 and forthcoming in Stephen Kay and Tapen Sinha (eds), Lessons from Pension Reform in the Americas, Oxford University Press.

Bayer, Patrick, Douglas Bernheim, and J. Karl Scholz (1996), "The Effects of Financial Education in the Workplace: Evidence from a Survey of Employers," NBER Working Paper n. 5655.

Bernheim, Douglas (1991), The Vanishing Nest Egg: Reflections on Saving in America, Twentieth Century Fund/Priority Press Publications, New York.

Bernheim, Douglas (1995), "Do Households Appreciate Their Financial Vulnerabilities? An Analysis of Actions, Perceptions, and Public Policy," Tax Policy and Economic Growth, Washington, DC: American Council for Capital Formation, pp. 1-30.

Bernheim, Douglas (1998), "Financial Illiteracy, Education and Retirement Saving," in Olivia S. Mitchell and Sylvester Schieber (eds.), Living with Defined Contribution Pensions, Philadelphia: University of Pennsylvania Press, pp. 38-68.

Bernheim, Douglas and Daniel Garrett (2003), "The Effects of Financial Education in the Workplace: Evidence from a Survey of Households," Journal of Public Economics, 87, pp. 1487-1519.

Browning, Martin and Annamaria Lusardi (1996), "Household Saving: Micro Theories and Micro Facts," Journal of Economic Literature, 34, pp. 1797-1855

Bucks, Brian and Karen Pence (2006), "Do Homeowners Know Their House Values and Mortgage Terms?” Working Paper, Federal Reserve Board of Governors.

Calvet, Laurent, John Campbell and Paolo Sodini (2005), "Down or Out: Assessing the Welfare Costs of Household Investment Mistakes," Harvard Institute of Economic Research Discussion Paper No. 2107.

Campbell, John (2006), “Household Finance," Journal of Finance, 61, pp.1553-1604. 
Caskey (2006), "Can Personal Financial Management Education Promote Asset Accumulation by the Poor? Mimeo, Networks Financial Institute, Indiana, IN.

Chan, Sewin and Ann Huff Stevens, (2003), “What You Don't Know Can't Help You: Knowledge and Retirement Decision Making," Working paper, New York University.

Choi, James, David Laibson, Brigitte Madrian and Andrew Metrick (2004), "Saving for Retirement on the Path of Least Resistance," In Edward J. McCaffrey and Joel Slemrod, editors, Behavioral Public Finance: Toward a New Agenda, pp. 304-351. New York:

Russell Sage Foundation, 2006.

Christelis, Dim trios, Tullio Jappelli, and Mario Padula (2005), "Health Risk, Financial Information and Social Interaction: the Portfolio Choice of European Elderly Households," Working paper. University of Salerno.

Clark, Robert and Madeleine D'Ambrosio (2002), "Saving for Retirement: The Role of Financial Education,” TIAA-CREF Institute Working Paper n. 4-070102-A.

Clark, Robert, Madeleine D'Ambrosio, Ann McDermed, and Kshama Sawant (2003), "Financial Education and Retirement Saving," TIAA-CREF Institute Working Paper 11-020103.

Clark, Robert and Sylvester Schieber (1998), "Factors Affecting Participation Rates and Contribution Levels in 401(k) Plans," in Olivia S. Mitchell and Sylvester Schieber (eds.), Living with Defined Contribution Pensions, Philadelphia: University of Pennsylvania Press, pp. 69-97.

Consejo, Asesor Presidencial para la Reforma Previsional (2006). Informe Ejecutivo, http://www.consejoreformaprevisional.cl/view/informe.asp

Duflo, Esther and Emmanuel Saez (2003), "The Role of Information and Social Interactions in Retirement Plan Decisions: Evidence from a Randomized Experiment," Quarterly Journal of Economics, 118, pp. 815-842.

Duflo, Esther and Emmanuel Saez (2004), "Implications of Pension Plan Features, Information, and Social Interactions for Retirement Saving Decisions,"in Olivia S. Mitchell and Stephen Utkus (eds.), Pension Design and Structure: New Lessons from Behavioral Finance, Oxford: Oxford University Press, pp. 137-153.

Employee Benefits Research Institute (1996), "Participant Education: Actions and Outcomes," Issue Brief, 169, January.

Gustman, Alan and Thomas Steinmeier (2004), “What People Don't Know about their Pensions and Social Security, "in William Gale, John Shoven and Mark Warshawsky (eds.), Private Pensions and Public Policies, Washington, DC: Brookings Institution, pp. 57-125. 
Hilgert, Marianne, Jeanne Hogarth and Sondra Beverly (2003), Household Financial Management: The Connection between Knowledge and Behavior," Federal Reserve Bulletin, pp. 309-322.

Hilgert, Marianne and Jeanne Hogarth (2002), "Financial Knowledge, Experience and Learning Preferences: Preliminary Results from a New Survey on Financial Literacy," Consumer Interest Annual, Vol. 48, 2002.

Hogarth, Jeanne, Christoslav E. Anguelov, and Jinhook Lee (2005), "Who Has a Bank Account? Exploring Changes Over Time, 1989-2001," Journal of Family and Economic Issues, Vol. 26, Number 1, March 2005.

John Hancock Financial Services (2002), Insights into Participant Investment Knowledge and Behavior, Eighth Defined Contribution Plan Survey.

Kimball, Miles and Tyler Shumway (2006), "Investor Sophistication, and the Participation, Home Bias, Diversification, and Employer Stock Puzzles," Mimeo, University of Michigan.

Lusardi, Annamaria (1999), "Information, Expectations, and Savings for Retirement," in Henry Aaron (ed.), Behavioral Dimensions of Retirement Economics, Washington, D.C.: Brookings Institution Press and Russell Sage Foundation, 1999, pp. 81-115.

Lusardi, Annamaria (2002), "Preparing for Retirement: The Importance of Planning Costs," National Tax Association Proceedings-2002, pp. 148-154.

Lusardi, Annamaria (2004), "Savings and the Effectiveness of Financial Education," in Olivia S. Mitchell and Stephen Utkus (eds.), Pension Design and Structure: New Lessons from Behavioral Finance, Oxford: Oxford University Press, pp. 157-184.

Lusardi, Annamaria and Olivia S. Mitchell (2006a), "Financial Literacy and Planning: Implications for Retirement Wellbeing," Working Paper, Pension Research Council, Wharton School, University of Pennsylvania.

Lusardi, Annamaria and Olivia S. Mitchell (2006b), "Baby Boomer Retirement Security: The Role of Planning, Financial Literacy, and Housing Wealth," forthcoming Journal of Monetary Economics.

Madrian, Brigitte and Dennis Shea (2001), "Preaching to the Converted and Converting Those Taught: Financial Education in the Workplace,” University of Chicago Working Paper.

Mandell, Lewis (2004), Financial Literacy: Are We Improving? Washington, D.C.: Jump\$tart Coalition for Personal Financial Literacy.

Mastrobuoni, Giovanni (2005), "Do Better-Informed Workers Make Better Retirement Choice? A Test Based on the Social Security Statement," Mimeo, Collegio Carlo Alberto. 
Carthy, David and John Turner (2000), "Pension Education: Does It Help? Does It Matter?" Benefits Quarterly (16), pp. 64-72.

Miles, David (2004), “The UK Mortgage Market: Taking a Longer-Term View,” Working Paper, UK Treasury.

Mitchell, Olivia. 1988. "Worker Knowledge of Pensions Provisions," Journal of Labor Economics, 6, pp. 21-39.

Moore, Danna (2003), "Survey of Financial Literacy in Washington State: Knowledge, Behavior, Attitudes, and Experiences," Technical Report n. 03-39, Social and Economic Sciences Research Center, Washington State University.

Muller, Leslie (2003), "Investment Choice in Defined Contribution Plans: the Effects of Retirement Education on Asset Allocation," Benefits Quarterly, 19, 76-94.

National Council on Economic Education (2005), "What American Teens and Adults Know About Economics," Washington, D.C.

Organization for Economics Co-Operation and Development (2005), Improving Financial Literacy: Analysis of Issues and Policies, Paris, France

Schreiner, Mark Clancy Margaret, and Michael Sherraden (2002), "Saving Performance in the American Dream Demonstration. A National Demonstration of Individual Retirement Accounts." Final Report, Center for Social Development. University of Washington, S. Louis.

Stango, Victor and Jonathan Zinman (2006), "Fuzzy Math and Red Ink: Payment/Interest Bias, Intertemporal Choice and Wealth Accumulation," Working Paper, Dartmouth College.

Sunden, Annika (2004), "How Do Individual Accounts Work in the Swedish Pension System"? Issue in Brief n. 22, Center for Retirement Research, Boston College. 
Table 1: Financial Literacy Among Early Baby Boomers

$($ HRS observations $=1,984)$

\begin{tabular}{|c|c|c|c|}
\hline Question Type & Correct (\%) & Incorrect (\%) & Do Not Know (\%) \\
\hline $\begin{array}{c}\text { Percentage } \\
\text { Calculation }\end{array}$ & 83.5 & 13.2 & 2.8 \\
\hline $\begin{array}{c}\text { Lottery } \\
\text { Division }\end{array}$ & 55.9 & 34.4 & 8.7 \\
\hline $\begin{array}{c}\text { Compound } \\
\text { Interest* }\end{array}$ & 17.8 & 78.5 & 3.2 \\
\hline $\begin{array}{c}\text { Political } \\
\text { Literacy }\end{array}$ & 81.1 & 11.0 & 7.7 \\
\hline
\end{tabular}

Notes: *Conditional on being asked the question. Percentages may not sum to 100 due to a few respondents who refused to answer the questions. Observations weighted using HRS household weights. Adapted from Lusardi and Mitchell (2006b). 
Table 2: Empirical Effects of Financial Literacy on Retirement Planning

Marginal Effects Reported (HRS observations $=1,716$ )

\begin{tabular}{|l|ccc|}
\hline & \multicolumn{3}{|c|}{ Probability of Being a Retirement Planner } \\
\hline & $\mathbf{1}$ & $\mathbf{2}$ & $\mathbf{3}$ \\
\hline Correct Percentage Calculation & -.016 & -.012 & -.034 \\
& $(.061)$ & $.062)$ & $.060)$ \\
Correct Lottery Division & $.059^{*}$ & .034 & .001 \\
& $(.030)$ & $(.031)$ & $.032)$ \\
Correct Compound Interest & $.153^{* * *}$ & $.149^{* * *}$ & $.114^{* * *}$ \\
& $(.035)$ & $(.035)$ & $.039)$ \\
Correct Political Literacy & $.104^{* * *}$ & $.084^{* *}$ & .016 \\
& $(.032)$ & $(.040)$ & $.042)$ \\
\hline DK Percentage Calculation & & .021 & .054 \\
& & $.068)$ & $(.067)$ \\
DK Lottery Division & & $-.154^{* * *}$ & $-.141^{* * *}$ \\
& & $(.050)$ & $(.051)$ \\
DK Compound Interest & & -.114 & -.073 \\
& & $.080)$ & $(.081)$ \\
DK Political Literacy & & -.019 & -.016 \\
& No & $(.053)$ & Yes \\
\hline Demographic controls & .031 & .038 & .074 \\
\hline \hline Pseudo R
\end{tabular}

Note: This table reports Probit estimates of the effects of literacy on planning; marginal effects reported. Analysis sample consists of HRS Early Baby Boomers who responded to financial literacy questions. Additional controls include age, education, race, sex, marital status, retirement status, number of children, and a dummy variable for those not asked the question about interest compounding. DK indicates respondent said he could not answer. Observations weighted using HRS household weights. * Significant at 10\%; ** significant at $5 \%$; *** significant at 1\%. Adapted from Lusardi and Mitchell (2006b). 
Table 3: The Effect of Retirement Seminars on Retirement Accumulation

\begin{tabular}{|c|c|c|c|c|}
\hline & Total sample & $1^{\text {st }}$ quartile & median & $3^{\text {rd }}$ quartile \\
\hline \multicolumn{5}{|c|}{ a. Financial net worth } \\
\hline Total sample & $17.6 \% * *$ & $78.7 \% * *$ & $32.8 \% * *$ & $10.0 \%$ \\
\hline Low education & $19.5 \%$ & $95.2 \% * *$ & $30.0 \% * *$ & $8.8 \%$ \\
\hline High education & $13.1 \%$ & $70.0 \% * *$ & $19.4 \% * *$ & $10.2 \%$ \\
\hline \multicolumn{5}{|c|}{ b. Total net worth } \\
\hline Total sample & $5.7 \%$ & $29.2 \% * *$ & $8.7 \%$ & $0.5 \%$ \\
\hline Low education & $3.4 \%$ & $27.0 \% * *$ & $7.1 \%$ & $4.0 \%$ \\
\hline High education & $7.3 \%$ & $26.5 \% * *$ & $6.5 \%$ & $3.6 \%$ \\
\hline \multicolumn{5}{|c|}{$\begin{array}{l}\text { c. Total net worth }+ \\
\text { Pensions }\end{array}$} \\
\hline Total sample & $20.5 \% * *$ & $32.7 \% * *$ & $26.8 \% * *$ & $19.5 \% * *$ \\
\hline Low education & $20.7 \% * *$ & $31.4 \% * *$ & $14.6 \% *$ & $18.2 \% * *$ \\
\hline High education & $19.4 \% * *$ & $39.3 \% * *$ & $31.2 \% * *$ & $17.6 \% * *$ \\
\hline \multicolumn{5}{|c|}{$\begin{array}{l}\text { d. Total net worth }+ \\
\text { Pensions and Social } \\
\text { Security }\end{array}$} \\
\hline Total sample & $16.0 \% * *$ & $18.6 \% * *$ & $20.4 \% * *$ & $17.2 \% * *$ \\
\hline Low education & $12.7 \% * *$ & $14.7 \% * *$ & $12.7 \% * *$ & $9.5 \% * *$ \\
\hline High education & $17.7 \% * *$ & $25.4 \% * *$ & $25.8 \% * *$ & $17.0 \% * *$ \\
\hline
\end{tabular}

Note: This table reports the percentage changes in different measures of retirement accumulation resulting from attending retirement seminars. Adapted from Lusardi (2004).

* indicates that the estimates from which percentages are based are statistically significant at the $10 \%$ level

** indicates that the estimates from which percentages are based are statistically significant at the $5 \%$ level 
Figure 1: Financial Literacy by Education and Race/Ethnicity: Early Baby Boomers (2004)

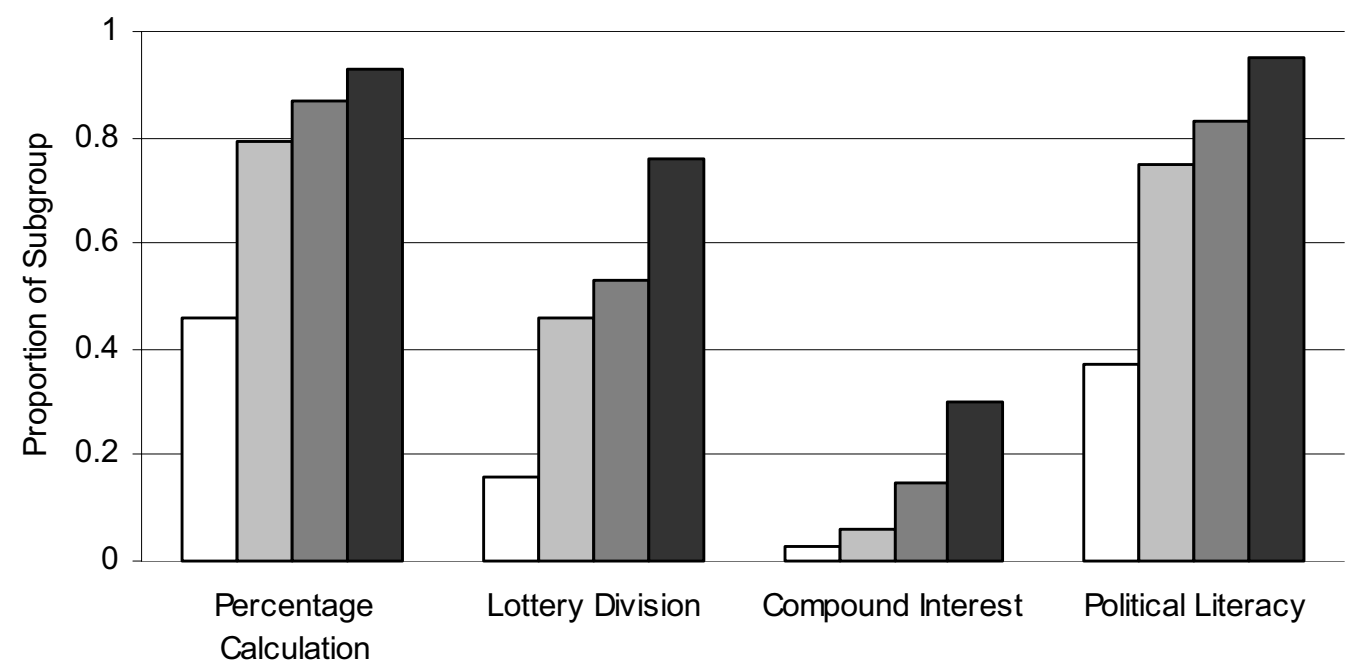

$\square$ Less than High School $\square$ High School $\square$ Some College $\square$ College or More

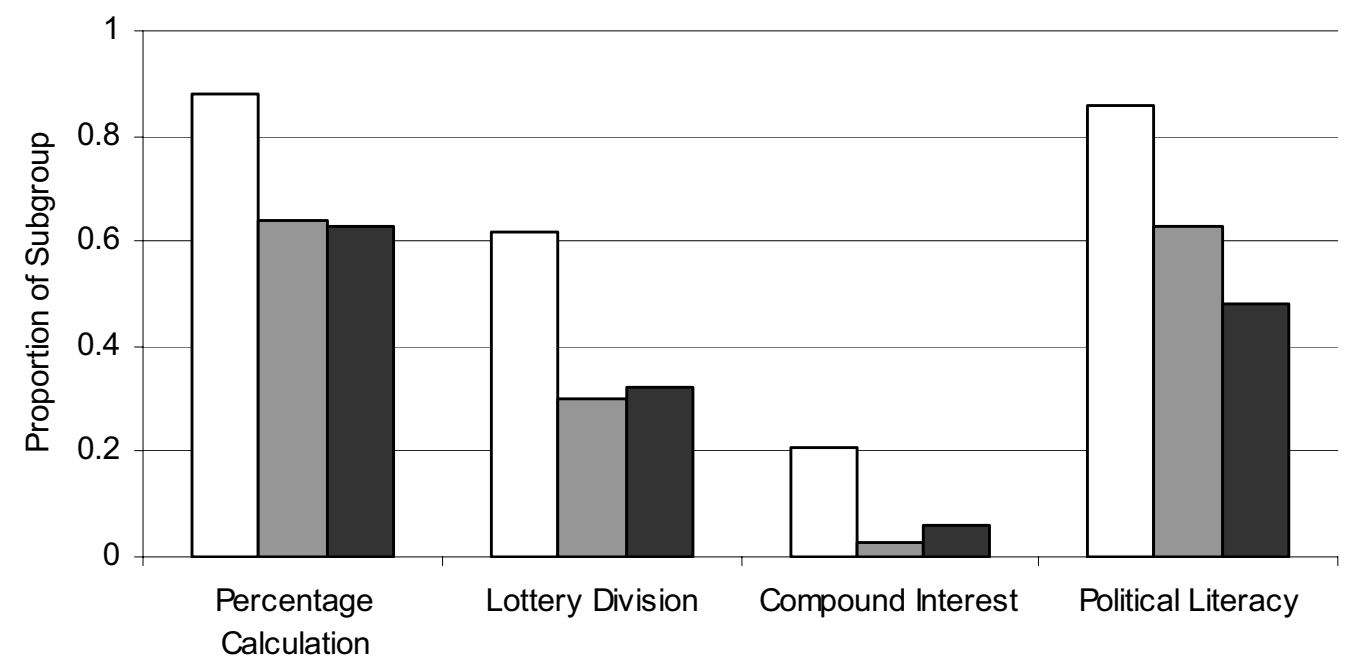

$\square$ White $\square$ Black $\square$ Hispanic

Note: Observations weighted using HRS household weights. Source: Lusardi and Mitchell (2006b). 


\section{CFS Working Paper Series:}

\begin{tabular}{lll} 
No. & Author(s) & Title \\
\hline 2007/14 & $\begin{array}{l}\text { Jean Boivin } \\
\text { Marc P. Giannoni } \\
\text { Ilian Mihov }\end{array}$ & $\begin{array}{l}\text { Sticky Prices and Monetary Policy: Evidence from } \\
\text { Disaggregated U.S. Data }\end{array}$ \\
& Virgiliu Midrigan & $\begin{array}{l}\text { Menu Costs, Multi-Product Firms, and Aggregate } \\
\text { Fluctuations }\end{array}$
\end{tabular}

2007/12 Michael Woodford

Robustly Optimal Monetary Policy with NearRational Expectations

Bayesian and Adaptive Optimal Policy under Lars E. O. Svensson Model Uncertainty

2007/11 Noah Williams

Mortgage Markets, Collateral Constraints, and Monetary Policy: Do

Alessandro Calza

$2007 / 10$

Tommaso Monacelli

Livio Stracca

Institutional Factors Matter?

Unemployment Fluctuations with Staggered

Mark Gertler

2007/09 Antonella Trigari

Nash Wage Bargaining

2007/08 Olivier Blanchard Jordi Galí

A New Keynesian Model with Unemployment

2007/07 Kai Christoffel

Keith Kuester

Tobias Linzert

Identifying the Role of Labor Markets for

Monetary Policy in an Estimated DSGE Model

2007/06 Gauti B. Eggertsson Banjamin Pugsley

The Mistake of 1937: A General Equilibrium Analysis

2007/05 Michael Bordo

Christopher Erceg

Three Great American Disinflations

Andrew Levin

Ryan Michaels

Copies of working papers can be downloaded at http://www.ifk-cfs.de 